\title{
REGIONAL-POTENTIAL-BASED PLANTATION VOCATION EDUCATION ANALYSIS IN EAST KALIMANTAN PROVINCE
}

\author{
Kautsar Eka Wardhana \\ Graduate School of Universitas Negeri Yogyakarta \\ kautsareka@yahoo.com \\ Sukamto \\ Graduate School of Universitas Negeri Yogyakarta \\ sukamto@uny.ac.id
}

\begin{abstract}
This study aims do provide plantation vocational education facilities in accordance with the needs of the plantation labor market for several years to come.This was a quantitative analyzing secondary data and setting the plantation vocational education needs by first making a projection of the population comprising the age group of 16-18 years in East Kalimantan Province.The research conclusions show: East Kalimantan Province need plantation vocational Education. The projection of plantation workers in East Kalimantan Province for 5 years to come from 2015 to 2019 on the whole experiences an increase in the needs for plantation workers continuously. In relation to the results of the projection for plantation workers in East Kalimantan Province for 5 years to come, the needs for vocational education in plantation in the province increase continuously.
\end{abstract}

Keywords: analysis vocational education planning, regional potentials 


\section{INTRODUCTION}

Based on projection released by Central Bureau of Statistics (BPS) in 2014, there is a rapidly growing population for the next twenty five years; 205.1 million population in 2000 becomes 273.2 in 2025 . It indicates that the national food supply should be sustainable with the population growth. However, Indonesia suffers the condition in reverse from the fact above. Indonesia as the agricultural country and abundant natural resources cannot afford to cover its domestic food supply, moreover it has to import them from another countries instead. "Indonesia has imported food products every year and it is irresistible to a chronic level. Almost 65 percents from overall domestic food needs are imported," exclaimed Natsir Mansyur, the Indonesia Vice Chief of Trade Chamber and Industry, Trade, Distribution, and Logistic Sector in Jakarta, Tuesday (September, 4th 2012). He said that import products kept on overflowing in this country since the decrease of food supply as the result of the low productivity performance. Innovation factor becomes one of many factors leads to low productivity.

Food needs and agricultural products projection is referred to population growth. Compared to 6.92 billions of people in 2010, world's growth population tends to rise 7.72 billions of people in 2020. According to the estimation, the food supply shall be well anticipated in case of fulfilling them rather than facing some shortage. It is considered to be beneficial if Indonesia can take an advantage from its demographic bonus in order to solve some problems all at once. The experts define the fine line: if the population keeps growing steadily, the food needs will leap to 35 percents in upcoming years, even in 2030.

Demographic bonus which is also well known as the window of opportunity is the one chance or even rare opportunity happens in one or two decades. The demographists estimate that this precious opportunity will occur in Indonesia around 2015-2030. While others argue that the years after this, population in the villages and the farming sectors are still the focus during the development in Indonesia. Arismunandar (2014, p. 59) proposed: Central Bureau of Statistics (BPS) predicts 44-45 percents of population in Indonesia still remain the farming labors in the villages if it is projected in 2020-2030.

Indonesia had persistently carried out the action of implementing demographic bonus through local economic potential improvement with economic corridor theme for the widespread potential and excellence in each area throughout Indonesia. Local economic potential development had 6 (six) economic corridors; Sumtera, Jawa, Kalimantan, Sulawesi, Bali-Nusa Tenggara, and Papua-Maluku. Government had made economic theme/map developed through these 6 economic corridors regarding to each local's excellence and strategic potential.

According to Engkoswara, Demographic bonus that leads to local excellence or 'local genius' is expandable potential resources in our lives that recently has not been fully empowered and left behind instead (Ali, 2007 , p. 346). The optimum potential enhancement can be an attractive excellent education for the locals. Ancient analogy proved that human being was so much dependent on the nature. Their massive dependency on water had initiated the first civilization around large and fertile rivers.

Local excellence of a region enable its inhabitants more to increase their living or the local revenue income (PAD) (Asmani, 2012, p. 30). The locals who yield advantages and income, manage to protect, preserve, and increase their local excellence quality that eventually strive the national and local competency for their own benefit. As the result, the pushed ahead local excellence will improve human resources quality in particular region.

Generally, Indonesia has not applied the regional based yet in case of its educational process. It means the education system in this country is still common within regions. Due to the establishment of six corridors development, education sector should correspondence to each of corridors. Somehow it is necessary to relate the labor needs and its availability. In the other words, education needs to be implemented on region or corridor based. The mapping of these 6 economic corridors can also be considered to define the type, location, quantity, quality, and time in accordance with education development.

Michael W. Galbraith (Zubaedi, 2005, p. 134) stated that education based on society is educational process which the individuals 
or adults become more competent in skill, attitude, and concept toward life and control local aspects from the society through democratic participation. Zakiya Daradjat (Wahjoetomo, 1997, pp. 42-43) claimed that society is a composition of individual and group bound by the unity of the state, culture, and religion. Every society own the goal, regulation, and particular authority system which connect to social life consequently influence each other in education.

Many researches study the relationship between local and education development. One of them is conducted by Seng (2007), studied the relationship between local development and vocational education in Singapore. Since the independence day in 1965, vocational education in Singapore had developed to deal with many stages of economic development. It was reconstructed and shifted from work based economics to capital based economics. Education system especially vocational guaranteed that the labors have knowledgment and skill relevant to the changes.

Sugiharto \& Kusmandari (2016) in International Journal of Information and Education Technology, entitled: Model Development in the Context of Vocational Village Community Empowerment in Central Java, concluded that vocational village program had succeeded to make villages into role model village. Each of them carried out the program to enhance its potential therefore new entrepreneurs were born and there were less of unemployees.

East Kalimantan Province is one of the region in Indonesia located in the middle of Kalimantan island which has corridor theme, "Production Center of Mining industry and National Energy Storage." Despite of well known mining industry production center, East Kalimantan has local potential in agriculture sector which is plantation sub sector, with $1,292,071$ hectares total area producing $7,692,281$ ton and employed 482.903 employees according to Department of Agriculture (2014). The largest area was planted with palm oil. The production yielded 7.600.298 ton from 1.115.415 hectares total area. The second biggest production was rubber tree plantation with 59.963 ton from 103.117 hectares total area. Palm oil trees length of area keeps on extending year to year as government program to launch " million hectares of palm oil trees" program followed by the building of manufacturing area. He stated that, "we cannot count on the using of coals, oils, and gasoline no more. We have come now to the act of making new locomotive through agriculture and plantation sector,...” Awang Faroek Ishak, East Kalimantan Governor (Ruslan, 2012).

If the development of plantation in East Kalimantan Province is not initially constructed from the plantation human resources development through qualified establishment of plantation human resources of education planning, East Kalimantan Province will not survive moreover it will be left behind for its dependency on coal and natural gasoline production that slowly decays. Through local potential based education needs analysis in Plantation vocational development strategy in East Kalimantan Province, the preparation and creation of qualified plantation human resources as one of the efforts to achieve future demographic bonus.

Clarke \& Winch (2007, p. 9) stated that, "vocational education is specialized to prepare an individual to work that emphasizes on practical and technical aspect." While according to Thompson (1972, p. xvi), vocational education is the education provides experiences, visible stimulus, awareness, information, or psychometric skill, and elevating exploration on vocational development process, establish, and maintaining the individual in the work field." Djojonegoro briefly stated that, "vocational education is the education that prepares learners to be well equipped in the work field."

From the regulation stated in Ministry of Education and Culture no.36/2014, vocational school according to verse 5 should fulfill the criterion: the availibility of local resources with particular vocational skill, vacancies potential, and society support from world business world industry. The establishment of education institution that fits local potential is much possible. Despite of this reason, we can not neglect the government regulation previously mentioned that the longer process is one of the concerns to permit the establishment of education unit. Hence this research uses adding learning group system rather than adding vocational school to insert new spectrum called plantation. Regulation of Ministry of Education and Culture no.36/2014 stated that learning group is "registered learning participants united in a class." The ideal numbers 
for a learning group is 32 learners coincides with Regulation of Ministry of National Education no. 69/2009, "Vocational schools program: 6 learning groups consist of 32 learners for each group." This study aims do provide plantation vocational education facilities in accordance with the needs of the plantation labor market for several years to come.

\section{RESEARCH METHOD}

This research is quantitative research with secondary data analysis from various organizations and official approved. The researcher obtain the data from East Kalimantan Province Central Bureau of Statistics (BPS), Department of Plantation, and Minstry of Agriculture. The problem of the research using secondary data is the validity and reliability. Analysis unit in secondary data analysis is rather different compared to other quantitative methods. Martono (2010, p. 10) described this point as: to determine validity and reliability matter is how the data is collected and obtained by the data provider. This kind of factor is unavoidable for secondary data users or in the other words this factor is out of control of the researcher. However, the researcher still needs to be aware and check from other related sources (if it is possible).

From this explanation, the researcher still can carry on the process and assume that the official data from the related institutions are valid and reliable.

In case of measuring the plantation labors needs in East Kalimantan Province, the researcher finds the obstacle to analyze since there is no availabilty of supporting data to calculate the labors needs. Inspite of that problem, the researcher still has references in form of supporting data; the plantation labors target from strategic plan of Department of Plantation East Kalimantan Province. Later, vocational school needs will refer to this strategic plan. Plantation vocational school needs analysis in East Kalimantan Province is performed in 3 stages:

\section{Grouping the Population Age}

Population data stated in Central Bureau of Statistics reports is range of five years in each group out of the group of school age, starts from 0-4 years old, 5-9 years old, 10-14 years old, 15-19 years old, 20-24 years old and etc. For the research purpose, the range of population age needed for vocational school level is 16-18 years old. Thus, the needed data is mixed up with the inappropriate age that range from 15-19 years old. The method used in analyzing population to know potential age for vocational school is to divide the population age by Sparague Multiplier Method which is done by arranging in particular way then multiply it with sprague multiplier number (Department of National Education, 2007, p. 5). Sprague multiplier number can be seen in Table 1.

Formula used in grouping population is:

$\mathrm{Fa}=\mathrm{Sla} \times \mathrm{F}-2+\mathrm{S} 2 \mathrm{a} \times \mathrm{F}-1+\mathrm{S} 3 \mathrm{a} \times \mathrm{F} 0+$ $\mathrm{S} 4 \mathrm{a} \times \mathrm{F} 1+\mathrm{S} 5 \mathrm{a} \times \mathrm{F} 2$

Note :

$\mathrm{Fa}$ : Population according to first year range

F0 : Population with age grouping

F1 : First age group of population after F0

F2 : Second age group of population after F0

F-1 : First age group of population before F0

F-2 : Second age group of population before F0

S1a : First Sprague Multiplier Number for a years old

S2a : Second Sprague Multiplier Number for a years old

S3a : Third Sprague Multiplier Number for a years old

S4a : Forth Sprague Multiplier Number for a years old

S5a : Fifth Sprague Multiplier Number for a years old

\section{Population Projection}

Population projection is conducted to analyze condition or population number according to the required age for the future thus the counting of population projection shall begin from 2015 till 2019. Next, projection of population number at vocational school age range from 16-18 years old. The counting of population projection is due to population growth following exponential function with this formula:

$$
P_{n}=P_{0}(1+r)^{n}
$$

Explanation:

$P_{n}$ : Population of year $\mathrm{n}$

$P_{0}$ : Population of year 0 or first year

$r$ : population growth number

$n$ : Variance between projection year and firstyear 


\section{Learning Group Needs}

The calculation of learning group needs is assumed with 32 students in one learning group (ideal number for 1 learning group). Before counting learning group needs, labor needs per year shall be calculated first as the graduation needs reference. The researcher has basis of Data Center and Agriculture Information System based on the counting of age grouping. The labors age which has to be fulfilled or replaced by the age range from 1519 years old is what the researcher has to take as a reference in line with the fact that the age is at the school level then other grouping age will face the regeneration as ssen in table 2 . Therefore, the total presentation of plantation labors is 4 percents based on this grouping age. The availability of plantation labors toward the graduate ones is 4 percents from total plantation labors per district/city. The counting of learning group needs is described below:

$$
\begin{aligned}
& (L G N)=\frac{\text { Plantation labor } \times 4 \%}{32 \text { students }(1 \text { learning group })} \\
& \text { LGN }=\text { Learning Group Needs }
\end{aligned}
$$

\section{RESEARCH RESULTS AND DISCUSSION}

Table 3 reveals the amount of population in East Kalimantan Province in 2013 and 2014 based on group of age and gender. The overall population elevates 75 thousands inhabitants from $3,275,844$ (2013) to $3,351,432$ (2014) inhabitants

The grouping at population of 16-18 years old, in 2013 the population grows 55,649 inhabitants while in 2014 the population changes to 55,216 inhabitants,

After conducting the grouping population age, 5 next years projection is carried out from 2015 until 2019 with the following explanations, vocational school students population in East Kalimantan Province in 2015 is 224,971 ; in 2016 the population is 222,635 ; in 2017 the population is 220,325 ; in 2018 the population is 218,037; and in 2019 the population is 215,774 . Population with age level 16-18 years old can be classified as raw parti- cipation number at high school level (Table $5)$.

Table 6 shows that high school and vocational school data in East Kalimantan Province in 2014, high school has absorbed 57,165 students or $33 \%$ from APK at age level 16-18 and vocational school has absorbed 60,709 students or $35 \%$ from APK. Approximately there is about $32 \%$ from APK of age level 16-18 have not been served yet.

Department of Plantation East Kalimantan Province has marked the plantation labors of 5 commodities (palm oil, rubber, cocoa, coconut, and pepper) for 5 years in accordance with Renstra (described in table 7) so that the required labors each year revealed in research method is $4 \%$ from the targeted labors, shown in table 7.

If there is a combination between table 6 and 8, there will be an adding toward plantation vocatinal school that solve the APK problem which approximately there are $9 \%$ in $2015 ; 10 \%$ in $2016 ; 10 \%$ in $2017 ; 11 \%$ in 2018; and $12 \%$ in 2019 have not been served yet (table 8 ).

Overall, East Kalimantan Province needs on plantation labors and vocational education will rise in the next 5 years; 20,452 labors and 639 learning groups in 2015; 21,474 labors and 671 learning groups in 2016; 22,548 labors and 705 learning groups in 2017; 23,675 labors and 740 learning groups in 2018; 24,858 labors and 777 learning groups in 2019. According to Regulation Policy No. 23/2014, education is managed in this following; Central Government runs the higher education (dikti), Provincial Government runs secondary education (dikmen), and District Government runs elementary education (dikdas). Instead of the efficiency and focus that this type of management has, the success and failure happen to each level education are much easily detected and repaired immediately. As well as the plantation vocational school needs applied thoroughly in district/city will enable the efficient search toward the opening of plantation vocational education. 
Table 1. Sprague Multiplier Number Level 16-18 Years Old

\begin{tabular}{cccccccc}
\hline \multirow{2}{*}{ Age } & $0-4$ & \multirow{2}{*}{$5-9$ year } & $\begin{array}{c}10-14 \\
\text { year }\end{array}$ & $\begin{array}{c}15-19 \\
\text { year }\end{array}$ & $\begin{array}{c}\text { 20-24 } \\
\text { year }\end{array}$ & $\begin{array}{c}25-29 \\
\text { year }\end{array}$ & $\begin{array}{c}30-34 \\
\text { year }\end{array}$ \\
& year & F-2 & F-1 & \multicolumn{1}{c}{ F0 } & \multicolumn{1}{c}{ F1 } & \multicolumn{1}{c}{ F2 } & F3 \\
\hline 15 years old & & $-0,0128$ & 0,0848 & 0,1504 & $-0,0240$ & 0,0016 & \\
16 years old & & $-0,0016$ & 0,0144 & 0,2224 & $-0,0416$ & 0,0064 & \\
17 years old & & 0,0064 & $-0,0336$ & 0,2544 & $-0,0336$ & 0,0064 & \\
18 years old & & 0,0004 & $-0,0416$ & 0,2224 & 0,0144 & $-0,0016$ & \\
19 years old & & 0,0016 & $-0,0240$ & 0,1504 & 0,0848 & $-0,0128$ & \\
\hline
\end{tabular}

(Source: Department of National Education 2007, p. 10)

Table 2. Population of Men and Women of 15 years old above Working in Plantation Sub Sector According to The Grouping Age and Projection Year 2015-2019

\begin{tabular}{crrrrrr}
\hline Group Age & $\begin{array}{c}\text { August } \\
2012\end{array}$ & $\begin{array}{c}\text { August } \\
\left.2015^{*}\right)\end{array}$ & $\begin{array}{c}\text { August } \\
\left.2016^{*}\right)\end{array}$ & $\begin{array}{c}\text { August } \\
\left.2017^{*}\right)\end{array}$ & $\begin{array}{c}\text { August } \\
\left.2018^{*}\right)\end{array}$ & $\begin{array}{c}\text { August } \\
\left.2019^{*}\right)\end{array}$ \\
\hline $15-19$ & 5.007 & 4.892 & 5.101 & 5.130 & 5.103 & 5.281 \\
$20-24$ & 14.591 & 14.256 & 14.864 & 14.949 & 14.869 & 15.390 \\
$25-29$ & 15.078 & 14.731 & 15.360 & 15.448 & 15.366 & 15.904 \\
$30-34$ & 23.464 & 22.925 & 23.903 & 24.039 & 23.912 & 24.749 \\
$35-39$ & 13.168 & 12.865 & 13.414 & 13.491 & 13.419 & 13.889 \\
$40-44$ & 17.163 & 16.769 & 17.484 & 17.584 & 17.491 & 18.103 \\
$45-49$ & 11.274 & 11.015 & 11.485 & 11.550 & 11.489 & 11.891 \\
$50-54$ & 10.137 & 9.904 & 10.327 & 10.386 & 10.330 & 10.692 \\
$55-59$ & 3.357 & 3.280 & 3.420 & 3.439 & 3.421 & 3.541 \\
$60+$ & 6.901 & 6.742 & 7.030 & 7.070 & 7.033 & 7.279 \\
Jumlah & 120.140 & 117.379 & 122.388 & 123.086 & 122.433 & 126.719 \\
\hline
\end{tabular}

(Source: Ministry of Agriculture, 2013, pp. 201-205)

Table 3. Population of East Kalimantan Province Based on Group Age and Gender

\begin{tabular}{crrrrrr}
\hline \multirow{2}{*}{ Group Age } & \multicolumn{1}{c}{2013} & \multicolumn{3}{c}{2014} \\
\cline { 2 - 7 } & \multicolumn{1}{c}{$\mathrm{L}$} & \multicolumn{1}{c}{$\mathrm{P}+\mathrm{P}$} & \multicolumn{1}{c}{$\mathrm{L}$} & \multicolumn{1}{c}{$\mathrm{P}$} & $\mathrm{L}+\mathrm{P}$ \\
\hline $0-4$ & 174.714 & 165.910 & 340.624 & 176.700 & 168.531 & 345.231 \\
$5-9$ & 161.085 & 151.022 & 312.107 & 162.487 & 152.254 & 314.741 \\
$10-14$ & 152.806 & 144.153 & 296.959 & 154.658 & 145.789 & 300.447 \\
$15-19$ & 147.141 & 138.964 & 286.105 & 148.542 & 140.155 & 288.697 \\
$20-24$ & 155.321 & 144.045 & 299.366 & 155.295 & 144.373 & 299.668 \\
$25-29$ & 162.183 & 147.706 & 309.889 & 163.791 & 148.725 & 312.516 \\
$30-34$ & 159.165 & 144.348 & 303.513 & 162.022 & 147.101 & 309.123 \\
$35-39$ & 148.043 & 130.326 & 278.369 & 151.823 & 134.137 & 285.960 \\
$40-44$ & 130.286 & 113.686 & 243.972 & 134.617 & 117.484 & 252.101 \\
$45-49$ & 106.914 & 92.147 & 199.061 & 112.129 & 96.793 & 208.922 \\
$50-54$ & 81.416 & 68.142 & 149.558 & 85.770 & 72.433 & 158.203 \\
$55-59$ & 58.926 & 46.069 & 104.995 & 62.579 & 49.921 & 112.500 \\
$60-64$ & 37.584 & 28.261 & 65.845 & 40.903 & 30.712 & 71.615 \\
$65-69$ & 20.770 & 18.090 & 38.860 & 22.773 & 19.530 & 42.303 \\
$70-74$ & 11.947 & 11.749 & 23.696 & 12.690 & 12.354 & 25.044 \\
$75+$ & 10.617 & 12.308 & 22.925 & 11.294 & 13.067 & 24.361 \\
\hline Total & 1.718 .918 & 1.556 .926 & 3.275 .844 & 1.758 .073 & 1.593 .359 & 3.351 .432 \\
\hline
\end{tabular}

(Source: BPS East Kalimantan Province, 2014 \& 2015) 
Table 4. Grouping Age Result level 16-18 years old in 2013-2014

\begin{tabular}{cccccccccc}
\hline \multirow{2}{*}{ Year } & \multicolumn{4}{c}{ Population Based on Age of SMK Prov. Kal-Tim } & \multicolumn{4}{c}{ Total of Age } \\
\cline { 2 - 10 } & \multicolumn{2}{c}{ Age 16 } & \multicolumn{2}{c}{ Age 17 } & \multicolumn{2}{c}{ Age 18 } & & 16-18 \\
& L & P & L & P & L & P & L & P & L+P \\
\hline 2013 & 29.591 & 27.972 & 57.563 & 29.463 & 27.832 & 57.295 & 28.641 & 27.008 & 55.649 \\
2014 & 29.243 & 27.693 & 56.936 & 29.149 & 27.581 & 56.729 & 28.409 & 26.807 & 55.216 \\
\hline
\end{tabular}

Table 5. Projection Result of Population Age 16-18 years old

Based on Gender in East Kalimantan Province

\begin{tabular}{|c|c|c|c|c|c|c|c|c|c|c|}
\hline \multirow{3}{*}{ Age } & \multicolumn{10}{|c|}{$\begin{array}{c}\text { Projection Year Population at Age 16-18 } \\
\text { East Kalimantan Province }\end{array}$} \\
\hline & \multicolumn{2}{|c|}{2015} & \multicolumn{2}{|c|}{2016} & \multicolumn{2}{|c|}{2017} & \multicolumn{2}{|c|}{2018} & \multicolumn{2}{|c|}{2019} \\
\hline & $\mathrm{L}$ & $\mathrm{P}$ & $\mathrm{L}$ & $\mathrm{P}$ & $\mathrm{L}$ & $\mathrm{P}$ & $\mathrm{L}$ & $\mathrm{P}$ & $\mathrm{L}$ & $\mathrm{P}$ \\
\hline 16 & 28.899 & 27.417 & 28.559 & 27.143 & 28.223 & 26.873 & 27.891 & 26.605 & 27.563 & 26.339 \\
\hline 17 & 56.316 & 28.838 & 55.702 & 28.531 & 55.096 & 28.227 & 54.496 & 27.926 & 53.902 & 27.628 \\
\hline 18 & 27.332 & 56.169 & 27.086 & 55.614 & 26.842 & 55.064 & 26.599 & 54.520 & 26.360 & 53.982 \\
\hline Total & 112.547 & 112.424 & 111.347 & 111.288 & 110.161 & 110.164 & 108.986 & 109.051 & 107.825 & 107.949 \\
\hline $\mathrm{L}+\mathrm{P}$ & \multicolumn{2}{|c|}{224.971} & \multicolumn{2}{|c|}{222.635} & \multicolumn{2}{|c|}{220.325} & \multicolumn{2}{|c|}{218.037} & \multicolumn{2}{|c|}{215.774} \\
\hline
\end{tabular}

Table 6. The Sum of School, Teacher, Student, Population at Age 16-18 SMA/MA and SMK Based on District/ City in East Kalimantan Province year 2014

\begin{tabular}{crrrrrrrr}
\hline \multirow{2}{*}{ No. } & \multirow{2}{*}{ District/ City } & Population & \multicolumn{3}{c}{ SMA/MA } & \multicolumn{3}{c}{ SMK } \\
\cline { 5 - 9 } & & Age 16-18 & School & Student & Teacher & School & Student & Teacher \\
\hline 1 & Paser & 13.694 & 18 & 4.068 & 357 & 12 & 3.913 & 368 \\
2 & Kutai Barat & 9.311 & 21 & 3.181 & 333 & 13 & 3.013 & 279 \\
3 & Kutai Kartanegara & 36.520 & 51 & 12.445 & 1.044 & 39 & 11.056 & 941 \\
4 & Kutai Timur & 14.688 & 21 & 4.666 & 369 & 22 & 5.133 & 426 \\
5 & Berau & 9.410 & 18 & 4.545 & 399 & 15 & 2.701 & 317 \\
6 & Penajam Paser Utara & 8.252 & 8 & 2.542 & 194 & 9 & 2.920 & 264 \\
7 & Balikpapan & 29.904 & 20 & 9.657 & 666 & 29 & 8.643 & 779 \\
8 & Samarinda & 44.984 & 36 & 11.888 & 937 & 54 & 20.084 & 1.641 \\
9 & Bontang & 7.636 & 11 & 3.511 & 291 & 13 & 3.069 & 364 \\
10 & Mahakam Ulu & 1.318 & 5 & 662 & 62 & 2 & 177 & 35 \\
\hline \multicolumn{2}{r}{ Total } & 175.717 & 209 & 57.165 & 4.652 & 208 & 60.709 & 5.414 \\
\hline
\end{tabular}

Source: BPS East Kalimantan 2015 (data is processed)

Table 7. Target, Indicator dan Target of Renstra Department of Plantation East Kalimantan Province (2014-2018)

\begin{tabular}{|c|c|c|c|c|c|c|c|}
\hline \multirow[b]{2}{*}{ Target } & \multirow[b]{2}{*}{ Indicator } & \multirow{2}{*}{$\begin{array}{c}\text { First } \\
\text { Condition } \\
\left(2013^{*}\right)\end{array}$} & \multicolumn{5}{|c|}{ Working Target of Year } \\
\hline & & & 2015 & 2016 & 2017 & 2018 & $2019 * *$ \\
\hline $\begin{array}{l}\text { The Increase of } \\
\text { Plantation Labors (TKP) }\end{array}$ & $\begin{array}{l}\text { The Sum of Plantation } \\
\text { Labor (person) }\end{array}$ & 463.753 & 511.288 & 536.852 & 563.695 & 591.879 & 621.466 \\
\hline $\begin{array}{l}\text { The Making of Palm Oil } \\
\text { Plantation }\end{array}$ & $\begin{array}{l}\text { The Expansion of } \\
\text { Plantation Width (Hectares) }\end{array}$ & 1.000 .000 & 1.240 .000 & 1.360 .000 & 1.480 .000 & 1.600 .000 & 1.720 .000 \\
\hline $\begin{array}{l}\text { The Making of Rubber } \\
\text { Plantation }\end{array}$ & $\begin{array}{l}\text { The Expansion of } \\
\text { Plantation Width (Hectares) }\end{array}$ & 93.463 & 97.463 & 99.463 & 101.463 & 103.463 & 105.463 \\
\hline $\begin{array}{l}\text { The Making of Cocoa } \\
\text { Plantation }\end{array}$ & $\begin{array}{l}\text { The Expansion of } \\
\text { Plantation Width (Hectares) }\end{array}$ & 17.453 & 18.500 & 19.000 & 19.500 & 20.000 & 20.500 \\
\hline $\begin{array}{l}\text { The Making of Coconut } \\
\text { Plantation }\end{array}$ & $\begin{array}{l}\text { The Expansion of } \\
\text { Plantation Width (Hectares) }\end{array}$ & 18.727 & 19.727 & 20.227 & 20.727 & 21.227 & 21.727 \\
\hline $\begin{array}{l}\text { The Making of Pepper } \\
\text { Plantation }\end{array}$ & $\begin{array}{l}\text { The Expansion of } \\
\text { Plantation Width (Hectares) }\end{array}$ & 6.466 & 7.466 & 7.966 & 8.466 & 8.966 & 9.466 \\
\hline
\end{tabular}

*) Temporary Number year 2013

**) researcher calculation on pattern based

(Source: Department of Plantation East Kalimantan Province 2013, p.54) 
Table 8. Target of Graduation per Year to Fulfill The Plantation Labor Availibility in East Kalimantan Province

\begin{tabular}{lrrrrr}
\hline \multirow{2}{*}{\multicolumn{1}{c}{ Indicator }} & \multicolumn{5}{c}{ Target of Graduation Per Year \& } \\
& \multicolumn{4}{c}{ Grouping Learning Needs } \\
\cline { 2 - 5 } & \multicolumn{1}{c}{2015} & \multicolumn{1}{c}{2016} & 2017 & \multicolumn{1}{c}{2018} & 2019 \\
\hline Target of Graduation (4\% of TKP*) & 20.452 & 21.474 & 22.548 & 23.675 & 24.858 \\
Grouping Learning Needs & 639 & 671 & 705 & 740 & 777 \\
\hline
\end{tabular}

*) $T K P=$ Plantation Labors

\section{CONCLUSION AND SUGGESTION}

\section{Conclusion}

The research result as an examined main problem which has been revealed leads researcher comes to a conclusion that plantation vocational school needs in line with plantation labors needs concludes $4 \%$ plantation labors per projection year in East Kalimantan Province so the researcher gain this following data; $4 \%$ plantation labors per projection year in East Kalimantan Province, 639 learning groups will be needed in 2015; 671 learning groups in 2016; 705 learning groups in 2017; 740 learning groups in 2018; and 777 learning groups in 2019.

\section{Suggestions}

First, to Central and Local Government, this type of education model can be Piloting Project to develop education model in preparing labors and minimizes the unemployees additionally to society prosperity improvement in case of reducing the poverty; Second, to related institutions such as the existing companies may apply this research in form of building private schools which its graduates automatically hired by the company itself; Third, to the future researchers and education experts, this research can be developed to other sectors according to each local potential. And fourth, Further research is required although it is in a macro province regional level of research. The research should be carried out in detail through subdistrict level in order to put plantation vocational education facilites correctly and precisely.

\section{REFERENCES}

Ali, M. (2009). Education for National Development. Bandung: PT. Imperial Bhakti Utama.

Arismunandar, S. (2014). Megatrends 2030:
Indonesia will be a Role Player in Asia. Aktual, 59.

Asmani, J.M. (2012). Education based on local excellence. Yogyakarta: Diva Press.

Central Bureau of Statistics (BPS). (2014). Retrieved October 9, 2014, from http://www.bps.go.id/

Central Bureau of Statistics (BPS) of East Kalimantan Province (2014). East Kalimantan in number 2014. Samarinda: Central Bureau of Statistics (BPS) of East Kalimantan Province. Retrieved April 3, 2016, from http://kaltim.bps.go.id/index.php/publika si/index?Publikasi\%5BtahunJudul\%5D= \&Publikasi\%5BkataKunci\%5D=timur+d alam+angka\&yt $0=$ Tampilkan\&Publikasi _page $=2 \#$

Central Bureau of Statistics (BPS) of East Kalimantan Province. (2015). East Kalimantan in number 2015. Samarinda: Central Bureau of Statistics (BPS) of East Kalimantan Province. Retrieved April 3, 2016, from http://kaltim.bps.go.id/index.php/publika si/index?Publikasi\%5BtahunJudul\%5D= \&Publikasi\%5BkataKunci\%5D=timur+d alam+angka\&yt $0=$ Tampilkan\#

Clarke, L \& Winch. C. (2007). Vocational education international approach, development and system. New York: Routledge.

Departement of National Education. (2007). Education projection technique. Jakarta: Research and Development Institution.

Department of Plantation in East Kalimantan Province. (nd). Final Draft Strategic Planning (RENSTRA) Department of Plantation of East Kalimantan Province .2013-2018. Samarinda: Department of 
Plantation of East Kalimantan Province .

Djojonegoro, W. (1998). Development of human resources through vocational school (SMK). Jakarta: PT Jayakarta Agung Offset.

Martono, N. (2010). Quantitative research method (context dan analisis data sekunder). Jakarta: PT. RajaGrafindo Persada.

Matin. (2013). The basic planning of education. Jakarta: PT. RajaGrafindo Persada.

Ministry of Agriculture. (2013). Analysis and Projection of Agriculture Sector Labors. 2013-2019. Retrieved April 3, 2016, from

http://pusdatin.setjen.pertanian.go.id/stat istika-193-analisis-dan-proyeksi-tenagakerja-sektor-pertanian-20132019.html

Regulation of Ministry of National Education No. 24/2007 About Standart of Facilities

Regulation of Ministry of National Education no. 69/2009 About Non-persona Operation Budget Standart 2009 for Elementary School (SD/MI), Junior High School (SMP/MTS), High School (SMA/MA), Vocational School (SMK), Elementary School for Special Needs Students (SDLB), Junior High School for Special Needs Students (SMPLB), High School for Special Needs Students (SMALB).

Regulation of Ministry of Education and Culture Republik Indonesia No.36 /2014 About A Manual to Establish, Change, and Shut Elementary and Secondary Education Unit. Ruslan, B. (2012). Palm Oil tree Becomes Economics New Locomotive in East Kalimantan. Retrieved August 8, 2014, from http://www.antaranews.com/berita/3211 3/kelapa-sawit-jadi-lokomotif-barueknomi-kaltim

Seng, L. S. (June 22). Vocational technical education and economic development the Singapore experience. This paper is based on a presentation first made to members of a World Bank Delegation on an Asian Education Study Visit to the Institute of Technical Education, Singapore. Retrieved October 9, 2014, from http://heeap.asu.edu/sites/default/files/V ocational\%20Technical\%20Education\% 20and\%20Economic\%20Development $\%$ 20 -

\%20The\%20Singapore\%20Experience.p df

Sugiharto, D.Y. P \& Kusumandari, R. B (2016). Model development in the context of vocational village community empowerment in Central Java. International Journal of Information and Education Technology,6(7). Retrieved from http://www.ijiet.org/vol6/752T3003.pdf

Thompson, J.F. (1972). Foundations of vocational education: Social and philosophical concepts. prentice-hall, Inc. New Jersey: Englewood Clifts.

Regulations of Republik Indonesia No. 23 year 2014 about Local Government.

Wahjoetomo (1997). University in form of Pesantren Education as future Alternative. Jakarta: Gema Insani Press.

Zubaedi. (2005). Society based education:An effort of offering solutions toward various social problem. Yoyakarta: Pustaka Pelajar. 